\section{Turkish adaptation of questionnaire on \\ attitudes towards engineers and scientists}

\begin{tabular}{ll}
\hline Received: & 28 May 2017 \\
Revised: & 20 Sept. 2017 \\
Accepted: & 21 Sept. 2017 \\
ISSN: 1307-9298 \\
Copyright @ IEJEE \\
www.iejee.com
\end{tabular}

DOI: $10.26822 /$ iejee.201713189

\begin{abstract}
The aim of this research was to present the Turkish adaptation of the survey for Middle-School Students' Attitudes toward Engineers and Scientists prepared by Lyons, Fralick and Kearn (2009) 32 items in a 5-point Likert type scale. The questionnaire was administered to 707 students receiving education in the fifth, sixth, seventh and eighth grades in state schools in the Ministry of National Education. Exploratory Factor Analysis (EFA) and Confirmatory Factor Analysis (CFA) were used to examine the structural validity of the questionnaire. SPSS 21 and LISREL 8.7 software were used for EFA and CFA, respectively. A structure consisting of 22 items and two factors, and accounting for $41.88 \%$ of total variance was obtained after the EFA. To evaluate the questionnaire's reliability, Cronbach's Alpha internal consistency coefficient, corrected-item total correlation and the significance of differences between item averages of meta-groups and subgroups (27\%) were evaluated using t-test. Cronbach's alpha internal consistency coefficient was found to be .83 for the overall questionnaire. As a result of the study, the Turkish adaptation of the questionnaire, prepared for determination of secondary school students' attitudes towards scientists and engineers, was conducted and a valid and reliable measurement tool was obtained.
\end{abstract}

Keywords: Secondary school students, attitudes towards engineers and scientists, questionnaire adaptation

\section{Introduction}

In today's world of scientific and technological developments that are taking place at an unprecedented pace, personal skills such as creativity and innovation, critical thinking and problem-solving, communication and cooperation, media literacy, information literacy and technology literacy are referred to as the $21^{\text {st }}$ century skills (P21, 2015). Science, technology, engineering and mathematics (STEM) education holds particular importance for development of twenty first century skills (Bybee, 2010; NRC, 2010). As one of the most important educational initiatives of the last decade, STEM education is a multi-disciplinary approach that aims to provide an integrated education for students in the disciplines of science, technology, engineering and mathematics (Daugherty, 2013; Kuenzi, 2008).

The reforms related with the accomplishment of STEM education hold great importance for economic development of Turkey. Vision 2023 of the Ministry of National Education (MoNE) 2014 strategic plan are among the projects initiated for this purpose. Other documents supporting STEM education policies in Turkey are; Higher Education Strategic Plan, Lifelong Learning Strategy Paper, and Turkish Industry and Business Association's (TUSIAD) Vision-2050 report for Turkey (Çorlu, Capraro, \& Capraro, 2014). In the 2015-2019 Strategic Plan, the Ministry of National Education (MoNE) included statements for the enhancement of STEM, and in the STEM Education Report issued in June 2016, the action plan related to STEM was determined. In the prepared action plan, the primary actions to be taken were determined as; establishment of
STEM Training centers, providing cooperation between the established centers and universities, providing teachers with trainings in these fields and updating the related curricula (MoNE, 2016). In line with this action plan, engineering and design skills were included in the draft curriculum of science courses and released to the public for their opinions by the Ministry of National Education in 2017. Providing students with an interdisciplinary point of view of problems, enabling them to make inventions, innovations and introduce new products with their acquired knowledge and skills, making them learn how to introduce new value added products, were aimed with this field of skills (MoNE, 2017). All these efforts are indicative of the determination to transform STEM education into a reform action in Turkey.

Akgunduz (2016) investigated the placement ratios of top 1000 students in STEM fields by placement tests of the Center for Evaluation, Selection and Placement (ÖSYM in Turkish), in the 2000-2014 period. As stated in the research results, placement percentages of the top 1000 students in STEM fields declined within this period. This ratio declined from $85.63 \%$ in 2000 to $27.88 \%$ in 2010 , and it was determined as $38.23 \%$ in 2014 . This situation reveals the necessity for taking immediate measures with regard to choosing STEM fields as professions and promoting the careers in these fields. In the same study, it was also pointed out that, students (in the top 1000) that did not prefer STEM fields particularly selected medical faculties.

Students' attitudes towards a profession and their knowledge level are highly effective on their future 
profession choices. Students start to take decisions as to their future professions in the early years of secondary school; therefore it is particularly important to provide students with information regarding STEM careers before and during secondary school years (Wyss, Heulskamp, \& Siebert, 2012). In the literature, numerous studies are available on the factors affecting the attitudes of students towards engineers and scientists, which are among the STEM careers. In these studies, several social and cultural factors were found to be effective on student attitudes towards engineers and scientists. These factors include; the living environment and parents (Barton, Hindin, Contento, Trudeau, Yang, Hagiwara, \& Koch, 2001; Schnabel, Alfeld, Eccles, Köller, \& Baumert, 2002); teachers and peers in schools (Lee 2002); and various media sources and popular culture (Long, Boiarsky, \& Thayer 2001; Steinke \& Long, 1996; Steinke, 2005).

The first descriptive study on student attitudes towards scientists was carried out by Mead and Metraux (1957). In their study, high school students were reported to define scientists as individuals wearing laboratory equipment and goggles, and performing dangerous experiments with test tubes in indoor laboratory environments. Following this study, a Draw a Scientist Test (DAST) (Chambers, 1983) was developed and used to determine students' perceptions of a scientist. Studies performed to determine the attitude towards scientists (Buldu, 2006; Chambers, 1983; Finson, 2002; Schibeci and Sorenson, 1983) indicate that, students' perceptions of a scientist generally involve a male individual with messy hair dealing with chemicals in laboratories, taking notes by using symbols; wearing glasses and a white lab coat.

With increasing importance attached to STEM education, researchers focused their attention on studies regarding the attitudes towards engineers. Initially, the researchers in the Boston Museum of Science determined student attitudes towards engineers using "Draw an Engineer" Test (DAET) which was an adaptation of "Draw a Scientist" Test (DAST) (Knight \& Cunningham, 2004). 3-12 $2^{\text {th }}$ grade students were asked the open-ended question "what does an engineer do?" along with drawings. Thirty percent of the students replied that they "build", 28\% "repair", 17\% "create", and "12\%" design. Based on the drawings made by students, researchers developed an evaluation tool consisting of sixteen visuals. With this evaluation tool, students were asked to choose among the things that an engineer is likely to do. In this research, participants were also asked the open-ended question: "an engineer is a ...........person" (Cunningham, Lachapelle \& LindgrenStreicher, 2005). In the results of the research which involved 504 students in $1^{\text {st }}-5^{\text {th }}$ grade, students stated that $78 \%$ of "engineers repair cars", $75.2 \%$ "lay cables", 70.7\% "operate machinery", 69.7\% "construct buildings", $67.1 \%$ establish factories and $63.5 \%$ develop machines. After the evaluation of the responses to the open-ended question, students were found to associate engineers with repairing, constructing and using tools.

In another research which involved the use of the same evaluation tool, a test was administered before and after a unit application from the program "Engineering is elementary". The final test results indicate that, students' attitudes towards engineering developed in the direction of making designs and team work, with a reduced level of misconceptions (Lachapelle \& Cunningham, 2007). A team of researchers from Purdue University investigated the effect of engineering summer camps on the attitudes of gifted primary school students towards engineering (Oware, Capobianco \& Diefes-Dux,2007; Oware, 2008). In the research which involved draw an engineer test, a survey and semi-structured interviews were conducted before and after the summer camp. At the beginning of the study, the majority of participating students associated engineers with physical work and construction work, while at the end of the camp, their perceptions of an engineer shifted to non-physical work and problem solving (Oware, 2008).

In another study, interviews were conducted to make a thorough evaluation of the drawings made by students. At the end of the research, students' perceptions of an engineer were gathered in four categories, namely "mechanic" who use vehicles and repair engines; "worker" who construct buildings, roads or repair, construct stuff; "technician" who use electronic devices and repair computers; and "designer". Only $17 \%$ of the students could state that an engineer makes design works (Capobianco, Diefes-Dux, Mena, \& Weller, 2011). In another study which evaluated the attitudes of seventh grade students towards engineers, students were found to have no knowledge as to what an engineer does, and which courses should be followed in high school to be an engineer (Spencer, 2011). In numerous studies, students failed to comprehend the difference between the work performed by engineers and qualified workers (Capobianco et al., 2011; Cunningham et al., 2005; Ergün, Emre \& Özel, 2016; Knight \& Cunningham, 2004; Montfort, Brown, \& Whritenour, 2013; Oware, 2008).

Few studies were encountered in the literature on the determination of secondary school students' attitudes towards engineers and scientists by use of a questionnaire (Gibbons, Hirsch, Kimmel, Rockland, \& Bloom, 2004; Lyons, Fralick, \& Kearn, 2009). Gibbons et al. evaluated the attitudes of secondary school students towards mathematics, science and engineering in addition to their knowledge level regarding engineering, by use of a questionnaire. This questionnaire was developed on the basis of another questionnaire that aimed to evaluate the knowledge and perceptions of students related to engineering (Hirsch, Gibbons, Kimmel, Rockland \& Bloom, 2003). More than $90 \%$ of participating students had received a good degree in their schools and participated in the summer camp program. $49 \%$ of students were informed about the occupations of engineers, $61 \%$ thought that engineers make life easier, and $56 \%$ stated that careers in science and mathematics fields were interesting and entertaining. When the students were asked to write five fields of engineering, only $7 \%$ gave a complete answer, and $51 \%$ gave either incorrect or incomplete answers while $65 \%$ of the students gave no answer or incorrect answers to the question "what an engineer does". $49 \%$ of the students could not exemplify the occupations of engineers although they knew what they do (Gibbons et al., 2004). As reported by Lyons et al., the majority of students were of the opinion that engineers are individuals occupied with boring works that make life easier with mathematics 
knowledge. They defined scientists as people who discover new information, seek the best way to solve a problem, use innovative ways in communication, earn a lot of money and use their brains while doing their work. Female students defined scientists as people who earn a lot of money, work alone, and carry out most of their works with their hands, whereas male students associated these attributes with engineers (Lyons et al., 2009).

Determination of student attitudes towards STEM fields and careers as from early years of primary and secondary school holds particular importance. This way, students' motivations towards STEM fields can be increased from early years by carrying out researches on development of their perceptions and attitudes, thereby achieving the goal of raising a new generation with the capability to innovate in STEM fields. No research was found in the Turkish literature related to the determination of secondary school students' attitudes towards engineers and scientists. In this context, the present research aimed to present a Turkish adaptation of the "Attitudes towards Engineers and Scientists" questionnaire (ATESQ) developed by Lyons et al. for secondary school students.

\section{Method}

The present research was carried out to contribute to the Turkish literature with an evaluation tool to determine secondary school students' attitudes towards engineers and scientists. Information on the study group, development stages of the questionnaire, studies on validity and reliability and analyses of the questionnaire are presented below.

\section{Study Group}

As a means for gaining speed and practicability, convenience sampling was used in determination of the study group (Yıldırım \& Şimşek, 2006). The study group consisted of 707 students, 368 (52\%) male and 339 (48\%) female students receiving education in 7 different state secondary schools of the Ministry of National Education (MoNE) as of the second term of 2016-2017 school year. 207 (29\%) of the students are fifth grade, $137(20 \%)$ sixth grade, 255 (36\%) are seventh grade and 108 (15\%) are eighth grade students. Reliability analyses were performed with this group of 707 students. Exploratory Factor Analysis (EFA) was used with 350 of the students; and Confirmatory Factor Analysis (CFA) was used with 357 of the students. Since the use of different samples is recommended for implementation of CFA and EFA (Fabrigar, Wegener, MacCallum \& Strahan, 1999), these two analyses were performed with data obtained from different study groups. Kass and Tinsley (1979) stated that at least 300 individuals should be reached for factor analysis, or at least 300-500 individuals should be reached to make a more accurate analysis with at least 5 times the number of items available in the questionnaire (cited in Seçer, 2015). Therefore, the sample in this research can be deemed sufficient for validity and reliability studies. Demographic information of the study group are given in Table 1.

Table 1. Demographic information of the study group (Descriptive Statics)

\begin{tabular}{|c|c|c|c|c|c|c|c|}
\hline \multirow[b]{2}{*}{ Analysis } & \multirow{2}{*}{$\begin{array}{c}\text { Gender } \\
\text { Grade }\end{array}$} & \multicolumn{2}{|c|}{ Female } & \multicolumn{2}{|c|}{ Male } & \multicolumn{2}{|c|}{ Total } \\
\hline & & $f$ & $\%$ & $f$ & $\%$ & $f$ & $\%$ \\
\hline \multirow{4}{*}{ Exploratory Factor Analysis } & 5. grade & 66 & 18.86 & 43 & 12.29 & 109 & 31.15 \\
\hline & 6. grade & 34 & 9.71 & 36 & 10.29 & 70 & 20.00 \\
\hline & 7. grade & 51 & 14.57 & 64 & 18.29 & 115 & 32.86 \\
\hline & 8. grade & 22 & 6.34 & 34 & 9.71 & 56 & 16.04 \\
\hline \multirow[t]{4}{*}{ Confirmatory Factor Analysis } & 5. grade & 42 & 11.76 & 56 & 15.69 & 98 & 27.45 \\
\hline & 6. grade & 20 & 5.60 & 47 & 13.17 & 67 & 18.77 \\
\hline & 7. grade & 79 & 22.13 & 61 & 17.09 & 140 & 39.22 \\
\hline & 8. grade & 25 & 7.00 & 27 & 7.56 & 52 & 14.56 \\
\hline \multirow[t]{4}{*}{ Reliability Analysis } & 5. grade & 108 & 15.27 & 99 & 14.00 & 207 & 29.27 \\
\hline & 6. grade & 54 & 7.64 & 83 & 11.74 & 137 & 19.38 \\
\hline & 7. grade & 130 & 18.39 & 125 & 17.68 & 255 & 36.07 \\
\hline & 8. grade & 47 & 6.65 & 61 & 8.63 & 108 & 15.28 \\
\hline
\end{tabular}

Attitudes towards Engineers and Scientists Questionnaire (ATESQ)

The questionnaire was developed by Lyons et al. to determine the attitudes of secondary school students towards engineers and scientists. The questionnaire consists of total 32 items, 16 for determination of engineer perceptions and 16 for determination of scientist perceptions. Same expressions were used for both engineer and scientist perceptions in the questionnaire. For instance the item "engineers are creative people" is also available as "scientists are creative people" in the questionnaire. The questionnaire used a 5point Likert type scale and no factor analysis study was found in the presentation by which the questionnaire was introduced (Lyons, et al., 2009).

\section{Procedures}

Validity

Language Validity

To receive the authors consent for Turkish adaptation of Attitudes towards Engineers and Scientists Questionnaire (ATESQ), Lyons, Fralick and Kearn were contacted via e-mail. In questionnaire adaptation studies, expressions' compliance with the language and culture of the original document holds critical importance. Translation of the questionnaire from English to Turkish was accomplished in two stages. In the 
first stage, Turkish translation was carried out independently by two linguists who are proficient in both languages. In the second stage, the translations were compared with two researchers and a linguist to adopt the expressions that were thought to be more descriptive. Afterwards, two researchers from Science Teaching Department reviewed the Turkish form of the questionnaire to make the final decision. The questionnaire was initially administered to 85 seventh and eighth grade students to evaluate its intelligibility. In the results, no impediment was observed in terms of its intelligibility, and the questionnaire was finalized for validity and reliability analyses.

Construct Validity (Factor Analysis)

Factor analysis was carried out to minimize the number of variables by defining a set of basic variables or factors among several observed variables. Each factor consists of a set of interrelated variables evaluating the same attribute as a result of the measurement of differences between the variables. In other words, factor analysis is the process of obtaining factors through grouping of interrelated variables upon calculation of the correlation between these variables based on the answers given by subjects (Ural \& Kılıç, 2005). As no factor analysis was applied in the original questionnaire, first Exploratory Factor Analysis (EFA) and then Confirmatory Factor Analysis (CFA) were implemented to reveal the implicit structure of the Attitudes towards Engineers and Scientists Questionnaire (ATESQ) and to verify this structure. SPSS 21 software was used for EFA and LISREL 8.7 software was used for CFA analyses.

\section{Findings}

Findings of Exploratory Factor Analysis

EFA was performed with the 32 items of the Attitude towards Engineers and Scientists Questionnaire. Prior to the analysis, Kaiser-Meyer-Olkin (KMO) coefficient and Bartlett test of sphericity were examined to verify the agreement of data with factor analysis. The coefficient $(>.60)$ and significant result of the Bartlett test indicated the agreement of data for analysis (Büyüköztürk, 2017). KMO coefficient was found as .89 and a statistically significant difference $\left(\chi^{2}=4987.35, p=.000\right)$ was observed after the Bartlett test of sphericity, thus verifying the agreement of data for factor analysis. 32 items of the questionnaire were subjected to Principle Component Analysis (PCA) and varimax (25) rotation was applied to determine which items belonged to which factor. The requirement for construct validity in questionnaires is obtaining a minimum difference of .10 between the two high factor loads of items gathered under different factors, and obtaining a factor load value equal to or higher than .45 . However this limit value can be reduced to .30 (Büyüköztürk, 2017). No item was found with factor load values lower than .30 .10 cyclic items (M3, M6, M11, M13, M16, M19, M22, M27, M29, M32) were excluded from the analysis. After EFA, ATESQ was found to have a construct with 22 items and two factors. In the scree-plot graph of the questionnaire, 2 factors with values higher than 1 seem to be prominent. Scree-plot graph of the questionnaire is given in Figure 1. The EFA results of ATESQ are given in Table 2.

Indicated in Table 2, 11 of 22 items are gathered under the first factor, and remaining 11 are gathered under the second factor as a result of Exploratory Factor Analysis (EFA). These two factors constitute the sub-dimensions of students' attitudes towards engineers and scientists. The first dimension is termed as attitude towards engineering, and the second is termed as attitude towards scientists. In Table 2, Factor load values at subfactor dimension are; between .51 and .70 for Factor 1 , and between .61 and .76 for Factor 2 .

The two factors in the questionnaire constitute $41.88 \%$ of the total variance. The first factor constitutes $23.005 \%$ and the second constitutes $18.875 \%$. Total variance of the factors is required to account for $41 \%$ of the total variance for a questionnaire to be applicable (Kline, 1994). Since the total variance of the two factors is $41.88 \%$, this questionnaire can be deemed applicable with a construct consisting of 22 items and 2 factors.

\section{Findings of Confirmatory Factor Analysis}

CFA was applied to test the data compliance of the model obtained using EFA. LISREL 8.7 software was used for data analysis. In CFA operations, by which the extent of the compliance of a predefined construct with the gathered data is verified, (Büyüköztürk, Akgün, Kahveci \& Demirel, 2004), the two-factor construct obtained after EFA was analyzed. The factor construct's fit was examined on the basis of the fit statistics and results of modification index. The indexes of the ATESQ calculated with CFA and those adopted in the literature (Çokluk, Şekercioğlu, \& Büyüköztürk, 2016) are given in Table 3.

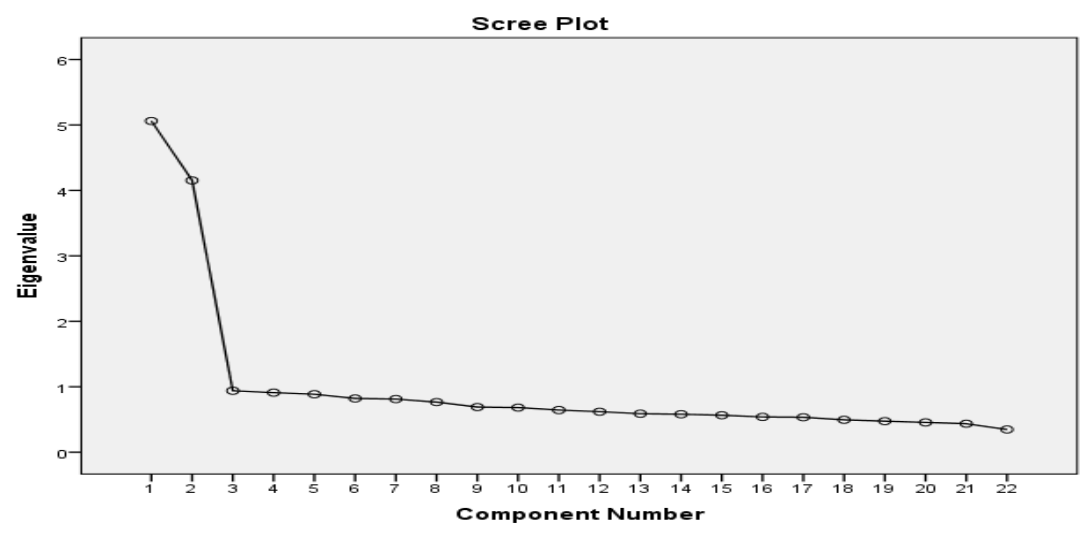


Table 2. EFA results of ATESQ

Figure 1. Scree-plot graph of the factors of ATESQ

\begin{tabular}{llll}
\hline Item No & Item & Factor 1 & Factor 2 \\
& & $\begin{array}{c}\text { Attitude } \\
\text { towards } \\
\text { engineers }\end{array}$ & $\begin{array}{c}\text { towards } \\
\text { scientists }\end{array}$ \\
& & & \\
\hline M1 & Engineers are occupied with several different works. & .609 & .604 \\
M2 & Engineers are creative people. & .511 & .688 \\
M4 & Engineers earn a lot of money. & .573 & .648 \\
M5 & Engineers make other people's lives easier. & .646 & .593 \\
M7 & Engineers are supposed to be good problem solvers. & \\
M8 & Engineers always adopt the best way of solving a problem. & \\
M9 & Engineers use several different ways to express their opinions. & \\
M10 & Engineers are supposed to be good in mathematics. & .610 & .575 \\
M12 & Engineers do most of their work using their brain. & .706 & .640 \\
M14 & Engineers explore new information. & & .642 \\
M15 & Engineers design new stuff. & & .481 \\
M17 & Scientists are occupied with several different works. & .716 \\
M18 & Scientists are creative people. & & .703 \\
M20 & Scientists earn a lot of money. & & .711 \\
M21 & Scientists make other people's lives easier. & & \\
M23 & Scientists are supposed to be good problem solvers. & & \\
M24 & Scientists always adopt the best way of solving a problem. & & .660 \\
M25 & Scientists use several different ways to express their opinions. & & .619 \\
M26 & Scientists are supposed to be good in mathematics. & & .671 \\
M28 & Scientists do most of their work using their brain. & \\
M30 & Scientists explore new information. & & \\
M31 & Scientists design new stuff. & & \\
\hline Revealed variance (\%) Total = 41.880 & & \\
\hline
\end{tabular}

Table 3. CFA results related to ATESQ

\begin{tabular}{|c|c|c|c|}
\hline Fit index & Criteria & Intercept points for confirmation & Research finding \\
\hline \multirow[t]{2}{*}{$\chi^{2}$} & $P>0.05$ & - & 330.11 \\
\hline & & & $s d=208, p=0.00$ \\
\hline$\chi^{2} / s d$ & - & $\leq 3=$ excellent fit & 1.58 \\
\hline \multirow[t]{2}{*}{ RMSEA } & 0 (excellent fit) & $\leq 0.05=$ excellent fit & 0.02 \\
\hline & 1 (no fit) & $\leq 0.08=$ good fit & \\
\hline \multirow[t]{2}{*}{ RMR } & 0 (excellent fit) & $\leq 0.05=$ excellent fit & 0.04 \\
\hline & 1 (no fit) & $\leq 0.08=$ good fit & \\
\hline \multirow[t]{2}{*}{ SRMR } & 0 (excellent fit) & $\leq 0.08=$ good fit & 0.02 \\
\hline & 1 (no fit) & & \\
\hline \multirow[t]{2}{*}{ GFI } & 0 (no fit) & $\geq 0.90=$ good fit & 0.97 \\
\hline & 1 (excellent fit) & & \\
\hline \multirow[t]{2}{*}{ AGFI } & 0 (no fit) & $\geq 0.90=$ good fit & 0.96 \\
\hline & 1 (excellent fit) & & \\
\hline \multirow[t]{2}{*}{ NFI } & 0 (no fit) & $\geq 0.90=$ good fit & 0.98 \\
\hline & 1 (excellent fit) & & \\
\hline \multirow[t]{2}{*}{ NNFI } & 0 (no fit) & $\geq 0.90=$ good fit & 0.99 \\
\hline & 1 (excellent fit) & & \\
\hline \multirow[t]{2}{*}{ CFI } & 0 (no fit) & $\geq 0.90=$ good fit & 0.99 \\
\hline & 1 (excellent fit) & & \\
\hline \multirow[t]{2}{*}{ PGFI } & 0 (no fit) & - & 0.76 \\
\hline & 1 (excellent fit) & & \\
\hline \multirow[t]{2}{*}{ PNFI } & 0 (no fit) & - & 0.84 \\
\hline & 1 (excellent fit) & & \\
\hline \multicolumn{2}{|c|}{ RMSEA: Root Mean Square Error of Approximation } & NFI: Normed Fit Index & \\
\hline \multirow{2}{*}{\multicolumn{2}{|c|}{$\begin{array}{l}\text { RMR: Root Mean Square Residuals } \\
\text { SRMR: Standardized Root Mean Square Residuals }\end{array}$}} & NNFI: Non-normed Fit Index & \\
\hline & & CFI: Comparative Fit Index & \\
\hline \multicolumn{2}{|c|}{ GFI: Goodness of Fit Index } & PGFI: Parsimony Goodness of Fit Index & \\
\hline \multicolumn{2}{|c|}{ AGFI: Adjusted Goodness of Fit Index } & PNFI: Parsimony Normed Fit Index & \\
\hline
\end{tabular}


As shown in Table 3, the obtained value of $\chi^{2} / \mathrm{sd}$ is 1.58 . In large samples a $\chi^{2} / \mathrm{sd}$ ratios lower than 3 indicates perfect fit; and those lower than 5 indicates moderate fit (Kline, 2005). In the present case, the obtained $\chi^{2} / s d$ can be assumed to yield a perfect fit. According to the obtained fit index values RMSEA and RMR seem to yield perfect fit values, whereas SRMR, GFI, AGFI, NFI, NNFI, CFI, PGFI and PNFI yield good fit values. An overall evaluation of fit index values indicates that, the built model yields a good fit. Also, $t$ values obtained for each of the items were evaluated and all items were found to be significant at $(p<.01)$ level.
These results show that the model is in agreement with the data. The path diagram showing the standardized coefficients between item-implicit variable and implicit variables is given in Appendix 1.

Findings regarding the Criterion Validity of the Questionnaire The relation between the mean scores obtained from the overall ATESQ and those separately obtained from attitude towards engineers and attitude towards scientists questionnaires were calculated with correlation analysis. Correlation analysis results are given in Table 4.

Table 4. Correlation between ATESQ and the Factors

\begin{tabular}{llll}
\hline Factors & Att. towards engineers & Att. towards scientists & Total \\
\hline Att. towards engineers & - & $0.74^{* *}$ & $0.76^{* *}$ \\
Att. towards scientists & & - & $0.77^{* *}$ \\
\hline P $^{* *}<01$ & &
\end{tabular}
$\mathrm{P}^{* *}<.01$

As shown in Table 4, high correlation values were obtained between the mean scores of overall ATESQ, and questionnaires for attitude towards engineers and attitude towards scientists questionnaire, with a significant relation at .01 level. According to Büyüköztürk (2017) the values between .70 and 1.0 are indicative of a significant correlation. Correlation coefficient results show that the factors constituting the questionnaire are in agreement and highly correlated within themselves and with the overall questionnaire.

\section{Findings regarding the Questionnaire's Reliability}

Cronbach alpha values of the questionnaire's dimensions were calculated to evaluate the reliability of the ATESQ. Also, corrected item-total correlation values were calculated to determine the extent to which the questionnaire items can distinguish individuals, and the significance of the differences between item mean values of the top $27 \%$ and the bottom $27 \%$ groups were examined with t-test. The obtained results are given in Table 5.

Table 5. Corrected item-total correlations of the ATESQ (Attitudes towards Engineers and Scientists Questionnaire) factors, and ttest results of top $27 \%$ and bottom $27 \%$ groups.

\begin{tabular}{|c|c|c|c|c|c|c|c|}
\hline $\begin{array}{l}\text { Factor's } \\
\text { name }\end{array}$ & Item No & $\begin{array}{l}\text { Corrected } \\
\text { item-total } \\
\text { correlation }\end{array}$ & $\begin{array}{l}\text { t(top \%27- } \\
\text { bottom } \\
\% 27)\end{array}$ & $\begin{array}{l}\text { Factor's } \\
\text { name }\end{array}$ & Item No & $\begin{array}{l}\text { Corrected item- } \\
\text { total correlation }\end{array}$ & $\begin{array}{l}\text { t(top \%27- } \\
\text { bottom } \\
\% 27)\end{array}$ \\
\hline \multirow{11}{*}{ 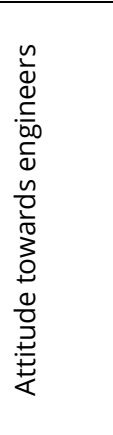 } & M1 & .34 & $9.54^{* \star}$ & \multirow{11}{*}{ 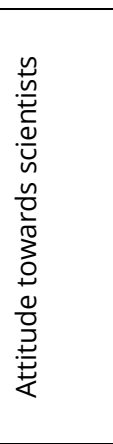 } & M17 & .42 & $11.49^{\star \star}$ \\
\hline & M2 & .31 & $10.77^{* *}$ & & M18 & .45 & $13.19^{* *}$ \\
\hline & M4 & .30 & $9.22^{* *}$ & & M20 & .29 & $9.00^{* *}$ \\
\hline & M5 & .35 & $11.62^{* *}$ & & M21 & .48 & $13.43^{* *}$ \\
\hline & M7 & .30 & $9.19^{* \star}$ & & M23 & .46 & $13.70^{* *}$ \\
\hline & M8 & .33 & $10.33^{* *}$ & & M24 & .49 & $12.93^{* *}$ \\
\hline & M9 & .33 & $10.94^{* *}$ & & M25 & .42 & $10.94^{* *}$ \\
\hline & M10 & .32 & $10.86^{* *}$ & & M26 & .37 & $10.94^{* *}$ \\
\hline & M12 & .33 & $10.01^{* *}$ & & M28 & .45 & $12.29^{* *}$ \\
\hline & M14 & .30 & $9.85^{* *}$ & & M30 & .53 & $13.81^{* *}$ \\
\hline & M15 & .34 & $11.64^{* *}$ & & M31 & .51 & $13.81^{* *}$ \\
\hline
\end{tabular}

$\star \star p<.01$

According to the results given in Table 5, corrected itemtotal correlation values of the items in the ATESQ vary between .30 and .53. In the evaluation of item-total correlation values, items with values equal to or higher than .30 are deemed sufficient in terms of the ability to distinguish the evaluated property (Büyüköztürk, 2017; Erkuş, 2012). All items in the questionnaire were found to meet this criterion. The results of t-test performed on the mean scores of the top and bottom $27 \%$ groups to determine the distinctiveness of the questionnaire indicated that a significant difference exists for all items. Significance of t-values, related to the differences between the top and bottom groups, is evidence of the distinctiveness of the items (Erkuş, 2012). On the basis of these findings, all items included in the questionnaire can be deemed distinctive.

Cronbach's alpha values, calculated for the Turkish form of the questionnaire are given in Table 6. 
Table 6. Cronbach's Alpha Values of the Attitudes towards Engineers and Scientists Questionnaire

\begin{tabular}{lll}
\hline Factor & Number of items & Cronbach Alpha Value \\
\hline Att. towards engineers & 11 & .84 \\
Att. towards scientists & 11 & .88 \\
Total & 22 & .83 \\
\hline
\end{tabular}

As shown in Table 6, Cronbach's alpha reliability value of 11 items in the first factor is .84 , that of the second factor consisting of 11 items is .88 , and Cronbach's alpha reliability value of the overall questionnaire ( 22 items) is .83. Given that the reliability coefficient values equal to or higher than .70 is deemed reliable (Büyüköztürk, 2017), the questionnaire can be considered reliable. The Turkish form of the questionnaire is given in Appendix 2.

\section{Evaluation of the Scores Received from ATESQ}

The ATESQ includes 22 items with a 5-point Likert type scale involving "absolutely agree", "agree", "indecisive", "disagree", "absolutely disagree" was used for the items to be answered in the questionnaire. The questionnaire comprises of a two-dimension structure namely attitudes towards engineers, and attitudes towards scientists. Each dimension involves 11 items. Therefore the scores received from the questionnaire varied between 11 and 55 . Both the scores received from sub-dimensions and those received from overall questionnaire were used while evaluating the scores received obtained from the ATESQ. The increase in the scores obtained from the subdimensions of the ATESQ and from the overall questionnaire is indicative of the increase in the perception level of students towards engineers and scientists.

\section{Results and Discussion}

The present study was carried out to present the Turkish adaptation of the ATESQ developed by Lyons, Fralich and Kearn (2009) and performed reliability and validity studies of the questionnaire. Exploratory Factor Analysis (EFA) was performed to examine the construct validity of the questionnaire, and the resulting construct was tested using Confirmatory Factor Analysis (CFA).

As a result of EFA, the questionnaire was found to have a two-dimension construct (attitudes towards engineers and scientists) that accounts for the 41.88 of the questionnaire's total variance. Since the total variance of the factors were required to account for $41 \%$ of the total variance in questionnaire development and adaptation studies (Kline, 1994), the construct validity of the questionnaire can be considered significantly good. Twofactor construct of the ATESQ was tested with EFA. The obtained fit values are $\chi^{2} / s d=1.58$; RMSEA $=0.02, \mathrm{RMR}=$ $0.04, \mathrm{SRMR}=0.02, \mathrm{GFI}=0.97, \mathrm{AGFI}=0.96, \mathrm{NFI}=0.98, \mathrm{NNFI}$ $=0.99, \mathrm{CFI}=0.99, \mathrm{PGFI}=0.76, \mathrm{PNFI}=0.84$. In evaluation of fit index values, RMSEA and RMR yielded excellent fit values and SRMR, GFI, AGFI, NFI, NNFI, CFI, PGFI and PNFI yielded good fit values. In the evaluation of overall fit index values, the performed EFA analysis is found to verify the model agreement of two-factor construct obtained as a result of EFA.

The t-test results, calculated by evaluation of top and bottom $27 \%$ groups indicate a significant difference for all item mean scores. Accordingly, the items of the questionnaire can be considered to have a distinctive character. The Cronbach's alpha value calculated for the attitude towards engineers-dimension of the ATESQ was found as .84, and that of the attitudes towards scientistsdimension of the ATESQ was found as .83. The calculated values verify the reliability of the questionnaire, considering that the values equal to or higher than .70 were reported to be reliable (Büyüköztürk, 2017). Also, the correlations between the mean scores obtained from attitudes towards engineers - attitudes towards scientists and those obtained from overall questionnaire were calculated to determine the criterion validity. The calculated correlation values varied between .74 and .77. In this respect, the questionnaire's level of fit for purpose can be considered to be significantly high.

Consequently, the ATESQ, which was adapted into Turkish, was found to consist of two factors, the model with two factors was found to be in agreement with the data obtained from participating students, internal consistency coefficients of the questionnaire's factors were found to be sufficient, and the questionnaire was found to serve its purpose. In light of these results, Turkish adaptation of the ATESQ can be considered as a valid and reliable evaluation tool in the determination of secondary school students' attitudes towards engineers and scientists.

\section{Recommendation}

The ATESQ questionnaire, adapted into Turkish in the present study, can be used to separately or collectively determine the secondary school student attitudes towards engineers and scientists. Researchers can also determine the correlations between secondary school students' attitudes towards engineers and scientists, and their attributes such as age, gender, grade, academic success and place of residence. A more in-depth analysis of student attitudes towards engineers and scientists can be performed by use of "Draw a Scientist" (DAST) and "Draw an Engineer" (DAET) tests in addition to the use of questionnaire and by conducting interviews. The effect of STEM activities performed at different grades on the attitudes of secondary school students towards engineers and scientists can also be investigated.

\section{References}

Akgunduz, D. (2016). A research about the placement of the top thousand students in STEM fields in Turkey between 2000 and 2014. Eurasia Journal of Mathematics, Science \& Technology Education, 12(5), 1365-1377.

Barton, A. C., Hindin, T. J., Contento, I. R., Trudeau, M., Yang, K., Hagiwara, S., \& Koch, P. D. (2001). Underprivileged urban mothers' perspectives on science. Journal of Research in Science Teaching, 38(6), 688-711.

Buldu, M. (2006). Young children's perceptions of scientists: a preliminary study. Educational Research, 48(1), 121-132. 
Büyüköztürk, Ş., Akgün, Ö., Kahveci, Ö. \& Demirel, F. (2004). The validity and reliability study of the Turkish version of the motivated strategies for learning questionnaire. Educational Sciences: Theory \& Practice, $4(2), 207-239$.

Büyüköztürk, ş. (2017). Data analysis handbook for social studies: Statistics, research pattern SPSS applications and interpretation (23th Ed.). Ankara: Pegem Academy.

Bybee, R.W. (2010). Advancing STEM Education: A 2020 Vision. Technology and Engineering Teacher, 70 (1), 3035.

Capobianco, B. M., Diefes-dux, H. A., Mena, I., \& Weller, J. (2011). What is an engineer? Implications of elementary school student conceptions for engineering education. Journal of Engineering Education, 100(2), 304-328.

Chambers, D. W. (1983). Stereotypic images of the scientist: The Draw-a-Scientist Test. Science Education, 67(2), 255-265.

Çokluk, Ö., Şekercioğlu, G., \& Büyüköztürk, Ş. (2016). Multivariate statistics for the social sciences: SPSS and LISREL applications (4th Ed.). Ankara: Pegem Academy.

Çorlu, M. S., Capraro, R. M., \& Capraro, M. M. (2014). Introducing STEM education: Implications for educating our teachers in the age of innovation. Education and Science, 39(171), 74-85.

Cunningham, C. M., Lachapelle, C., \& Lindgren-Streicher, A. (2005). Assessing elementary school students' conceptions of engineering and technology. American Society of Engineering Education, Portland, OR.

Daugherty, M. K. (2013). The Prospect of an "A" in STEM Education. Journal of STEM Education, 14 (2), 10-15.

Ergün, A., Emre, H., Özel, M. (2016). Determination of secondary school students' Perceptions towards engineering and technology. 12th national science and mathematics education congress, Adana, Turkey.

Erkuş, A. (2012). Evaluation and questionnaire development in psychology. Ankara: Pegem A Publishing.

Fabrigar, L. R., Wegener, D. T., MacCallum, R. C. \& Strahan, E. J. (1999). Evaluating the use of exploratory factor analysis in psychological research. Psychological Methods, 4(3), 272-299.

Finson, K. D. (2002). Drawing a scientist: What we do and do not know after fifty years of drawings. School Science and Mathematics, 102(7), 335-345.

Gibbons, S. J., Hirsch, L. S., Kimmel, H., Rockland, R., \& Bloom, J. (2004). Middle school students' Perceptions to and knowledge about engineering. International conference on engineering education, Gainesville, FL.

Hirsch, L. S., Gibbons, S. J., Kimmel, H., Rockland, R. \& Bloom, J. (2003). High school students Perceptions to and knowledge about engineering. Proceedings of the 33 st ASEE/IEEE Frontiers in Education Conference, Boulder, CO.

Kass, R. A., and Tinsley, H. A. (1979). Factor analysis. Journal of Leisure Research. 11, 120-138

Kılıç, İ., \& Ural, A. (2005). Scientific Research Process and Data Analysis with SPSS. Ankara: Detay Publisling.
Kline, P. (1994). An easy guide to factor analysis. London: Routledge.

Kline, R. B. (2005). Principles and practice of structural equation modeling (2nd Ed.). New York: Guilford.

Knight M. \& Cunningham C. (2004). Draw an engineer test (DAET): development of a tool to investigate students' ideas about engineers and engineering. ASEE Annual Conference Proceedings, Salt Lake City, UT, 4079-4089.

Kuenzi, J. J. (2008). Science, technology, engineering, and mathematics (STEM) education: Background, federal policy, and legislative action [Report for Congress]. Retrieved March 20, 2017, from http:// www.fas.org/sgp/crs/misc/RL33434.pdf

Lachapelle, C. P., \& Cunningham, C. M. (2007). Engineering is Elementary: Children's changing understandings of science and engineering. Presented at the Annual Conference of the American Society for Engineering Education, Honolulu, HI

Long, M., Boiarsky, G., \& Thayer, G. (2001). Gender and racial counter-stereotypes in science education television: A content analysis. Public Understanding of Science, 10(3), 255-269.

Lyons, J., Fralick, B., \& Kearn, J. (2009). A Survey of Middle Schoolers' Perceptions towards Engineers and Scientists. Annual Conference of the American Society for Engineering Education, Honolulu, $\mathrm{HI}$

Mead, M., \& Metraux, R. (1957). Image of the Scientist among High-School Students. Science, 126, 384-390.

Ministry of National Education [MoNe] (2016). STEM training report. Ministry of National Education General Directorate of Innovation and Education Technologies. Ankara.

Ministry of National Education [MoNe] (2017). Draft Curriculum for Science Courses. Ankara.

Montfort, D. B., Brown, S., \& Whritenour, V. (2013). Secondary Students' Conceptual Understanding of Engineering as a Field. Journal of Pre-College Engineering Education Research (J-PEER), 3(2), 2.

National Research Council (NRC). (2010). Exploring the intersection of science education and 2lst century skills: A workshop summary. Washington, DC: National Academies Press.

Oware, E., Capobianco, B., \& Diefes-Dux, H. A. (2007). Young children's perceptions of engineers before and after a summer engineering outreach course. Paper presented at the 37th ASEE/IEEE Frontiers in Education Conference, Milwaukee, WI

Oware, E. A. (2008). Examining elementary students' perceptions of engineers. Unpublished doctoral dissertation, Purdue University, USA.

P21 (2015). Framework for 21st Century Learning. Partnership for 21st Century Skills (P21). Retrieved March 20, 2017, from http://www.P21.org

Schibeci, R. A., \& Sorensen, I. (1983). Elementary school children's perceptions of scientists. School Science and Mathematics, 83(1), 14-20.

Schnabel, K. U., Alfeld, C., Eccles, J. S., Köller, O., \& Baumert, J. (2002). Parental influence on students' educational 
choices in the United States and Germany: Different ramifications-Same effect?. Journal of Vocational Behavior, 60(2), 178-198.

Seçer, i. (2015). Practical data analysis with Spss and lisrel software (2nd Ed). Ankara: Anı Publishing.

Spencer, M. E. (2011). Engineering perspectives of grade 7 students in Canada. Unpublished doctoral dissertation, Queen's University, Canada.

Steinke, J., \& Long, M. (1996). A lab of her own? Portrayals of female characters on children's educational science programs. Science Communication, 18(2), 91115.

Steinke, J. (2005). Cultural representations of gender and science: Portrayals of female scientists and engineers in popular films. Science Communication, 27(1), 27-63.

Wyss, V. L., Heulskamp, D., \& Siebert, C. J. (2012). Increasing middle school student interest in STEM careers with videos of scientists. International Journal of Environmental and Science Education, 7(4), 501-522.

Yıldırım, A. ve Şimşek, H. (2006). Qualitative research methods in social studies. Ankara: Seçkin Publishing. 
APPENDIX 1. Path Diagram of Attitudes towards Engineers and Scientists Questionnaire (ATESQ)

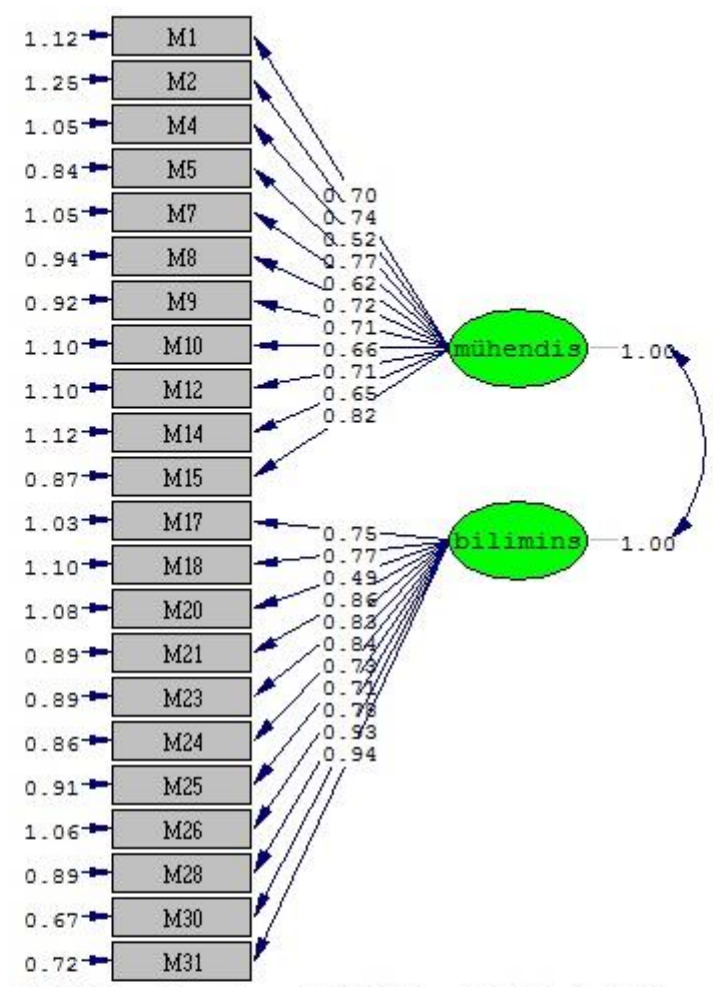

Chi-Square $=330.11, d f=208, P-v a l u e=0.00000, \quad$ RMSEA $=0.029$ 
APPENDIX 2. Turkish Form of Attitudes Towards Engineers and Scientists Questionnaire

\begin{tabular}{|c|c|c|c|c|c|c|}
\hline & ifadeler & $\frac{\varepsilon}{2}$ & & & & 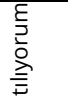 \\
\hline 1 & $\begin{array}{l}\text { Bilim insanları farklı birçok iş yaparlar. } \\
\text { Engineers are occupied with several different works. }\end{array}$ & & & & & \\
\hline 2 & $\begin{array}{l}\text { Bilim insanları yaratıcı insanlardır. } \\
\text { Engineers are creative people. }\end{array}$ & & & & & \\
\hline 3 & $\begin{array}{l}\text { Bilim insanları çok para kazanırlar. } \\
\text { Engineers earn a lot of money. }\end{array}$ & & & & & \\
\hline 4 & $\begin{array}{l}\text { Bilim insanları insanların hayatlarını kolaylaştııılar. } \\
\text { Engineers make other people's lives easier. }\end{array}$ & & & & & \\
\hline 5 & $\begin{array}{l}\text { Bilim insanlarının iyi sorun çözücü olmaları gerekir. } \\
\text { Engineers are supposed to be good problem solvers. }\end{array}$ & & & & & \\
\hline 6 & $\begin{array}{l}\text { Bilim insanları bir sorunu çözmenin daima en iyi yolunu kabul ederler. } \\
\text { Engineers always adopt the best way of solving a problem. }\end{array}$ & & & & & \\
\hline 7 & $\begin{array}{l}\text { Bilim insanları düşüncelerini anlatmak için farklı birçok yol kullanırlar. } \\
\text { Engineers use several different ways to express their opinions. }\end{array}$ & & & & & \\
\hline 8 & $\begin{array}{l}\text { Bilim insanlarının matematikte iyi olmaları gerekir. } \\
\text { Engineers are supposed to be good in mathematics. }\end{array}$ & & & & & \\
\hline 9 & $\begin{array}{l}\text { Bilim insanları işlerinin çoğunu beyinlerini kullanarak yaparlar. } \\
\text { Engineers do most of their work using their brain. }\end{array}$ & & & & & \\
\hline 10 & $\begin{array}{l}\text { Bilim insanları yeni bilgiler keşfederler. } \\
\text { Engineers explore new information. }\end{array}$ & & & & & \\
\hline 11 & $\begin{array}{l}\text { Bilim insanları yeni şeyler tasarlarlar. } \\
\text { Engineers design new stuff. }\end{array}$ & & & & & \\
\hline 12 & $\begin{array}{l}\text { Mühendisler farklı birçok iş yaparlar. } \\
\text { Scientists are occupied with several different works. }\end{array}$ & & & & & \\
\hline 13 & $\begin{array}{l}\text { Mühendisler yaratıcı insanlardır. } \\
\text { Scientists are creative people. }\end{array}$ & & & & & \\
\hline 14 & $\begin{array}{l}\text { Mühendisler çok para kazanırlar. } \\
\text { Scientists earn a lot of money. }\end{array}$ & & & & & \\
\hline 15 & $\begin{array}{l}\text { Mühendisler insanların hayatlarını kolaylaştırırlar. } \\
\text { Scientists make other people's lives easier. }\end{array}$ & & & & & \\
\hline 16 & $\begin{array}{l}\text { Mühendislerin iyi sorun çözücü olmaları gerekir. } \\
\text { Scientists are supposed to be good problem solvers. }\end{array}$ & & & & & \\
\hline 17 & $\begin{array}{l}\text { Mühendisler bir sorunu çözmenin daima en iyi yolunu kabul ederler. } \\
\text { Scientists always adopt the best way of solving a problem. }\end{array}$ & & & & & \\
\hline 18 & $\begin{array}{l}\text { Mühendisler düşüncelerini anlatmak için farklı birçok yol kullanırlar. } \\
\text { Scientists use several different ways to express their opinions. }\end{array}$ & & & & & \\
\hline 19 & $\begin{array}{l}\text { Mühendislerin matematikte iyi olmaları gerekir. } \\
\text { Scientists are supposed to be good in mathematics. }\end{array}$ & & & & & \\
\hline 20 & $\begin{array}{l}\text { Mühendisler işlerinin çoğunu beyinlerini kullanarak yaparlar. } \\
\text { Scientists do most of their work using their brain. }\end{array}$ & & & & & \\
\hline 21 & $\begin{array}{l}\text { Mühendisler yeni bilgiler keşfederler. } \\
\text { Scientists explore new information. }\end{array}$ & & & & & \\
\hline 22 & $\begin{array}{l}\text { Mühendisler yeni şeyler tasarlarlar. } \\
\text { Scientists design new stuff. }\end{array}$ & & & & & \\
\hline
\end{tabular}



This page is intentionally left blank

www.iejee.com 